\title{
Wallis and Futuna
}

National Cancer Institute

\section{Source}

National Cancer Institute. Wallis and Futuna. NCI Thesaurus. Code C17259.

A group of islands in the South Pacific Ocean, about two-thirds of the way from Hawaii to New Zealand, northeast of Fiji and west of American Samoa. 